\title{
ФОРМУВАННЯ ТА ДІЯЛЬНІСТЬ ОРГАНІЗАЦІЙНО- МОБІЛІЗАЦЙННХ РЕФЕРЕНТУР ЗАПІЛЛЯ УПА НА ВОЛИНІ ТА ПОЛІССІ (1943-1944 рр.)
}

У статті досліджені особливості становлення, організаційно-мобілізаційних референтур запілля УПА на Волині та Поліссі, їх структура, склад. Проаналізовані основні засади їх функціонування, порядок виконання покладених на них завдань щодо обліку військовозобов'язаних та проведення мобілізації в УПА, вишкільна діяльність та організація самооборони населення.

Ключові слова: організаційно-мобілізаційні референтури, запілля, мобілізація, Волинь, Полісся.

Актуальність проблеми. Діяльність ОУН та УПА середини $\mathrm{XX}$ ст. упродовж останнього десятиліття є об’єктом уваги вітчизняних та зарубіжних дослідників. Тематика досліджень українського визвольного руху здебільшого стосується вивчення військової, політичної та пропагандистської діяльності структурних одиниць підпілля ОУН (б) різного рівня та територіальних угруповань українського повстанського війська, але питання діяльності таких важливих структур запілля УПА, як організаційномобілізаційні референтури залишаються малодослідженими.

Тому вивчення історичного досвіду діяльності організаційномобілізаційних референтур запілля УПА сприятиме удосконаленню діяльності мобілізаційних органів 3 питань обліку військовозобов'язаних, залученню їх до Збройних Сил України та інших військових формувань держави, організації територіальної оборони, особливо актуальних під час проведення бойових дій на Сході України та застереже від помилок, зроблених у минулому.

Історіографія та джерела. Формування та діяльність організаційно-мобілізаційних референтур запілля УПА на Волині та Поліссі було об'єктом зацікавлення науковців і дослідників.

Джерельна база дослідження складається в основному з наказів та звітів комендантів різних рівнів, організаційно-мобілізаційних референтів, а також списків (реєстрів) військовозобов'язаного та невійськовозобов'язаного населення, які знаходяться у фондах

Омельченко Ігор Григорович, старший викладач кафедри мобілізаційної, організаційно-штатної, кадрової роботи та оборонного планування, Національна академія сухопутних військ імені гетьмана Петра Сагайдачного, м. Львів.

(C) Омельченко I. Г., 2018 
Центрального державного архіву вищих органів влади і управління України у фонді 3838 «3’єднання північних груп Української повстанської армії «УПА-Північ» [14, 15], Державного архіву Рівненської області у фонді Р-30 «Колекція матеріалів ОУН-УПА, що діяли на території Рівненської області» [2, 3], документів та матеріалів, які опубліковані у новій серії «Літопису УПА» $[6,7,8,9]$.

Останнім часом з'явилось чимало наукових праць стосовно функціонування такого унікального явища в структурі визвольного руху, як запілля УПА, яке було сформовано з організаційної мережі ОУН (б). Вагомий внесок у наукове опрацювання даного питання зробили дослідники В. Ковальчук $[4,5]$, Г. Стародубець $[12,13]$, I. Патриляк [11], I. Марчук $[9,10]$ та О. Вовк [1] та інші.

Проте питання діяльності таких важливих структур запілля УПА, як організаційно-мобілізаційні референтури в українській історіографії залишаються в повній мірі не дослідженими.

Метою статті є висвітлити історичний досвід формування та діяльності організаційно-мобілізаційних референтур запілля УПА на Волині та Поліссі, аналіз основних напрямів діяльності та визначення ефективності їхньої роботи.

Виклад основного матеріалу. До літа 1943 р., внаслідок відсутності чіткої структури армії та розмежування функцій між ОУН та УПА, панувало своєрідне двовладдя [10, с. 102]. Тільки наприкінці літа на території північно-західних українських земель (далі - ПЗУЗ) відбувається поділ на безпосередньо функціонування УПА та запілля як військово-адміністративна діяльність ОУН (б) щодо забезпечення військ усіма необхідними ресурсами. Обласні проводи, які діяли з 1941 р., були розформовані, а територія ПЗУЗ організаційно була поділена на чотири оперативно-територіальні угруповання - військові округи (далі ВО): № 01 «Заграва» (північна частина Рівненської області), № 02 «Богун» (південна частина Рівненської області і Крем'янеччина), № 03 «Турів» (Волинська область, Берестейщина і Кобринщина) і № 04 «Тютюнник» (Житомирська область). Військовим округам підпорядковувались нижчі ланки: військові надрайони, військові райони, військові підрайони, кущі (якщо вони утворювались) та станиці [10, с. 102; 6, XVI, 11, с. 218]. Вказана система військовоадміністративного розподілу існувала лише в запіллі на ПЗУЗ і як справедливо зауважував історик І. Марчук керівництво запілля у ті часи практично було модифікованим крайовим проводом ОУН (б) на ПЗУЗ $[9$, с. 66]. 
Запіллям керував комендант, воно складалось 3 таких референтур: організаційно-мобілізаційної (виникла на базі існуючих раніше окремо організаційної та військової референтур - I.O.), суспільно-політичної, господарської, зв'язку Служби безпеки (СБ) та Управління Червоного Хреста (УЧХ) [4, с. 275; 11, с. 226; 6, с. XVI].

Проаналізувавши розпорядчі та звітні документи, які надходили від комендантів та організаційно-мобілізаційних референтів військових надрайонів та районів запілля, $є$ можливим визначити їх кадровий склад станом на осінь 1943 р. На прикладі звітів організаційно-мобілізаційного референта Рівненського надрайону ВО «Богун» «Тигра» за вересень та невідомого референта за листопад 1943 р. встановлено, що до їх складу входили канцелярія мобілізації у складі - шефа, 3-5 працівників, додатково до неї включались мобілізаційні інспектори, кожен з яких опікувався певним закріпленим за ним районом, та вишкільний інспектор [8, c. 703, 710]. На канцелярію покладались наступні обов'язки працівники канцелярії відпрацьовували персональну книгу, документацію 3 обліку військовозобов'язаних за сотнями та родами зброї, евіденційну книгу, друк вишкільних військових матеріалів, мобілізаційних листків. Мобілізаційні інспектори відповідали за ведення районних книг по роках, перевірку відповідності обліку військовозобов'язаних в районах та визначення місць, організацію обладнання мобілізаційних пунктів, перевірку виконання заходів підготовки до мобілізації та сповіщення осіб, що їй підлягали [8, с. 710]

Склад районних організаційно-мобілізаційних референтур був неоднорідний. Так, згідно реєстру старшин, які працюють у даній референтурі Олександрійського району № 20 Рівненського надрайону ВО «Богун», який у грудні 1943 р. склав його очільник «Прометей», вона складалась 3 референта, підреферента самооборони та чотирьох старших військовиків [8, с. 719, 720], а у районі «Лісний» Костопільського надрайону ВО «Заграва» у січні 1944 р. до неї входили референт та комендант самооборони [14, арк. 163]. Відповідно до апарату підрайону, станиці входили у референт підрайону та вишкільний інструктор [8, с. 71].

Аналіз персонального складу організаційно-мобілізаційних референтур свідчить про те, що їх головними завданнями були підготовка та проведення заходів мобілізації населення до 
підрозділів УПА, його вишкіл та організація самооборони. Але на етапі їх становлення мали місце випадки, коли заходи мобілізації проводились іншими структурами. Так у наказі № 2 від 15 серпня 1943 р. командир групи УПА «Богун» «Еней» суворо зауважував «Мобілізування людей до УПА переводить організаційномобілізаційний, а не СБ......, або і інший організаційний член» $[6$, с. 321,322$]$.

Надзвичайно важливим завданням, без якого неможливо було якісно проводити заходи мобілізації, була робота 3 обліку військовозобов'язаних. Згідно з донесеннями керівників радянських партизанських загонів, що діяли на терені, перша хвиля мобілізації на північно-західних українських землях (ПЗУЗ) проводилась протягом червня - серпня 1943 р. Так молодь із деяких сіл Костопільського району почали мобілізувати до УПА у червні 1943 р. Відомо, що 8 - 10 серпня того ж року було мобілізовано чоловіків віком 315 до 50 років у Володимирецькому районі. Схожі процеси відбувались у Рафалівському районі [5, с. 104]. При цьому в архівних справах перший розпорядчий документ щодо підготовки списків сільського населення у станицях датується 3 вересня 1943 р., коли організаційно-мобілізаційний референт ВО «Заграва» «Тарас» наказав скласти списки чоловічого та жіночого населення за відповідними віковими категоріями та за встановленим взірцем [8, с. 458].

Збереглись цікаві дані про виконання таких наказів. Так організаційно-мобілізаційний референт Костопільського району «Іскра» Костопільського надрайону ВО «Заграва» «Негус» у своєму звіті від 31 листопада 1943 р. доповідав про відпрацювання списків мешканців станиць чоловічої статі, народжених в роках від 1893 до 1925, віком від 18 до 50 років та жінок від 1913 до 1925, що відповідає віковому діапазону від 18 до 30 років [8, c. 463]. Подібні списки складались у інших станицях ПЗУЗ. На прикладі реєстраційного списку, який був складений на чоловіків села Клевань Рівненського району ВО «Богун» можна встановити, що обліковими ознаками чоловіків, які раніше служили у війську були: прізвище та ім'я, дата і місце народження, в якій армії проходив службу, рід зброї, військовий ступінь, військова спеціальність, цивільний фах та інші вмілості, сімейний стан (одружений або неодружений), родинний стан (кількість дітей), освіта, опінія (думка станичних та районних (кущових) зверхників, 
іноді представників СБ, про військовозобов'язаного, пов'язані зі станом здоров'я, а також схильність до зловживання спиртними напоями, підозрілий у зв'язках з НКВС - I.О.). Відповідно на чоловіків, які не проходили службу, у списках вказувались усі дані, окрім тих, що не пов'язані 3 військовою службою, але позначалась інформація стосовно проходження такими чоловіками військових вишколів [3, арк. 9 - 14, 14 зв]. Вказані облікові ознаки військовозобов'язаних враховувались для більш ефективного його використання під час комплектування відділів УПА, насамперед під час мобілізації. Щомісячні звіти про стан та діяльність організаційно-мобілізаційних референтур дають певну картину стану мобілізаційної роботи в окремих повстанських районах, зокрема у ВО «Заграва». Так на кінець грудня 1943 р. в Костопільському надрайоні налічувалось 16805 осіб військовозобов'язаних, із них 10483 рядових, 355 підстаршин та 9 старшин. В Сарненському надрайоні військовозобов'язаних було 12906 , в тому числі 3323 рядових, 112 підстаршин та 10 старшин [13, с. $76 ; 6$, с. 262,263$]$.

Також станичними військовими проводився облік мешканців, які пішли служити у Робітничо-Селянську Червону Армію (далі РСЧА) або були відправлені на роботу у Німеччину [15, арк. 7, 8].

Керівництво запілля вживало заходів щодо підвищення якості поповнення, яке направлялось у відділи УПА. Так організаційномобілізаційні референти ВО «Богун» та «Заграва» наказували своїм підлеглим структурам негайно створити лікарські пункти, для обстеження осіб, що підлягають мобілізації, а також наголошували, що мобілізовані люди, які направляються 3 надрайонів, повинні бути цілком здорові, прибувати на місце служби 3 лікарською довідкою, добре одягнені і взуті [6, с. 209, 430]. Але виконувались вказівки зверхників на місцях по-різному. Як свідчить звіт організаційно-мобілізаційного референта Камінь-Каширського району ВО «Турів» від 30 листопада 1943 р., лікарські огляди проводились в селах Личини, Качин, Качинська Вілька та Олександрія цього району, де серед 854 мешканців усього 64 особи, виявились непридатними до військової служби [4, с. 200]. При цьому згідно із звітом коменданта невстановленого військового району, що входив до надрайону «Долина» ВО «Заграва», за період з 28.10 по 17.11.1943 р. на території його відповідальності були складені списки військовозобов'язаних, але у зв'язку із 
браком лікаря жодної лікарської комісії не проводилось [14, арк. 134]. Тому працівники окремих організаційно-мобілізаційних референтур в силу неспроможності виконувати поставлені на них завдання були замінені [14, арк. 22, 28].

Значна увага також приділялась обліку мобілізованих до УПА. Організаційно-мобілізаційний референт ВО «Богун» «Тирса» у наказі від 24 листопада 1943 р. вказував «Вести по надрайонах сталий облік мобілізованих до УПА. Негайно подати дані про кількість мобілізованих за станом на 1.12 .43 р.» [6, с. 430]. На дані референтури покладалась опіка за родинами, вихідці з яких проходили службу в УПА. Це була функцієя, яка притаманна місцевим органам держави. У жовтні 1943 р. у Людвипільському районі «Скеля» Костопільського надрайону ВО «Заграва» були складені списки членів родин військових, котрі потребували допомоги [5, с. 108]. Згідно із звітами вищеназваного референта району «Скеля» «Кровного» від листопада та грудня 1943 p. референтурою проводились заходи щодо всебічного забезпечення родин вояків УПА. Усього було забезпечено тягловою силою 45 родин, хлібом, дровами, худобою - 34 родини [8, с. 461-462, 464].

Організаційно-мобілізаційні референтури безпосередньо займались питаннями вишкільної підготовки населення. Ними проводився вишкіл переважно чоловічого, іноді жіночого населення 3 військової та санітарної підготовки, готувались спеціалісти мінерної справи. Важливе значення надавалось військовій підготовці комендантів самооборони, які, в свою чергу, займались вишколом цивільного населення. По всіх теренах ПЗУЗ започатковано військовий вишкіл жіноцтва, яке здебільшого залучалось до санітарних вишколів, де їх навчали наданню санітарної, медичної допомоги [13, с. 77; 2, арк. 68]. У зв'язку із наближенням фронту набули актуальності вишколи зв'язківців та проведення занять 3 основ конспірації [13, с. 77].

Крім питань, пов'язаних 3 призовом чоловіків на військову службу, працівники організаційно-мобілізаційних референтур проводили роботу щодо створення розгалуженої мережі сільської самооборони. За архівними даними першим розпорядчим документом, згідно з яким через відповідних військових комендантів визначались їх завдання, був наказ першого командира УПА за підписом «Клим Савур» від 30 серпня 1943 р. № 8, у якому організаційно-мобілізаційним референтурам усіх рівнів 
було визначено завдання щодо організації ефективної самооборони населення, налагодження військового вишколу молоді, навчання військового впоряду, витривалості в маршах, проведення пробних алярмів [12, с. 206 - 207]. Серед мешканців підбирались люди, які за потреби могли просигналізувати повстанцям або жителям сусідніх сіл про наближення ворогів, стати на захист свого села чи, коли буде необхідно, приєднатися до акцій повстанців.

До їх обов'язків також входило накопичення зброї, постачання до війська таких військових предметів, як шинелі, плащ-палатки, наплічники, сумки до набоїв, ладівниці, паски, далековиди, мапи, польові сумки, компаси, артилерійські прилади (стереотруби, бусолі, панорами), телефонні апарати, телефонічні дроти, автомашини, мотоцикли й частини до них [6, с. 323-324].

Важливим завданням, що покладалось на організаційномобілізаційні референтури була протидія заходам мобілізації до РСЧА. Ними організовувались напади на військові комісаріати, знищення списків військовозобов'язаних у сільрадах. Народний комісар державної безпеки УРСР Савченко 18 травня 1944 р. у спецповідомленні Хрущову про факти зриву мобілізації у Рівненській області повідомляв, що 24 лютого 1944 р. до голови Кунінської сільради Мізоцького району явилось шість чоловік, одягнених у однострої військовослужбовців РСЧА, і під загрозою зброї забрали у нього списки військовозобов'язаних села [7, с. 216]. Відомі також випадки викрадення списків військовозобов'язаних у трьох сільрадах Тучинського району і заборони головам сільрад Олександрійського, Мізоцького, Володимирецького, Рафалівського та інших районів Рівненщини передавати списки до радянських військових комісаріатів [5, с. 105]. Ними проводились заходи активної контрпризовної агітаційної кампанії, напади з відбиванням колон новобранців на шляху до збірних пунктів радянських військкоматів. У вищезгаданому спецповідомленні народного комісара державної безпеки УРСР повідомлялося про факт відбиття та спрямування у ліс 75 військовозобов'язаних, які рухались на збірний пункт райвійськкомату, що був здійснений 12 березня 1944 р. за вказівкою організаційно-мобілізаційного референта села Сухівці В. Данилина «Воробель» [7, с. 217]. 
На основі викладеного можна зробити наступні висновки: Керівництво запілля у вкрай важких і несприятливих умовах в цілому зуміло організувати роботу організаційно-мобілізаційних референтур, які виконували дуже важливу роботу щодо вишколу населення і поставки його до відділів УПА. Крім головних функцій працівники організаційно-мобілізаційних референтур виконували важливі завдання щодо налагодження системи самооборони населення у селах, вчинення контрмобілізаційних заходів, збір зброї та предметів військового призначення, матеріальної допомоги сім'ям, вихідці з яких воювали в УПА. Отже, дані референтури відігравали значну роль у боротьбі УПА за визволення України, а досвід їх діяльності потребує всебічної уваги та подальшого вивчення.

1. Вовк $О$. Короткий нарис діяльності УПА та іiі запілля на ПЗУЗ і в прилеглих регіонах у $1943-1946$ рp. / О. Вовк // Український визвольний рух / Центр досліджень визвольного руху, Інституг українознавства ім. І. Крип'якевича НАН України. - Львів, 2006. - Збірник 8. - С. 164-224.

2. Державний архів Рівненської області (далі - ДАРО) Ф. Р-30. - On. -2. - Спр. 33. -310 арк.

3. ДАРО. - Ф. Р-30. - On. - 2. - Спр. 53. -35 арк.

4. Ковальчук В. Діяльність ОУН(б) і Запілля УПА на Волині й південному Поліссі (1941-1944рр.)/ В. Ковальчук. - Львів; Торонто: В-во «Літопис УПА», 2006. (Серія «Бібліотека», т. 7) - 512 с.

5. Ковальчук В. Організаційні референтури ОУН (б) і запілля УПА у світлі джерел (Волинь I Полісся, 19431944 рр.). / В. Ковальчук // Український визвольний рух. Львів, 2006. - Збірник 6. - С. 95-108.

6. Літопис Української Повстанської Армії (далі Літопис УПА). Нова серія. - Київ; Торонто, 1999. - Т. 2: Волинь і Полісся: УПА та запілля 1943 - 1944. Документи і матеріали / [ред. П. Сохань, Є. Штендера та ін.; упоряд. О. Вовк, І. Павленко]. - 724 с.

7. Літопис УПА. Нова серія. - Київ; Торонто, 2000. Т. 4: Боротьба проти УПА і націоналістичного підпілля: інформаційні документи ЦК КП(Б)У, обкомів партії, НКВС-МВС, МДБ-КДБ (1943-1959). Книга перша: (19431945) / [ред. П. Сохань, П. Потічний та ін.; упоряд. А. Кентій, В. Лозицький, І. Павленко]. - 597 с.

8. Літопис УПА. Нова серія. - Київ; Торонто, 2007. Т. 11: Мережа ОУН(б) і запілля УПА на території ВО «Заграва», «Турів», «Богун» (серпень 1942 - грудень 1943 рр.) / [ред. П. Сохань, П. Потічний та ін.; упоряд. В. Ковальчук]. -848 с. 
9. Марчук I. Командир УПА-Північ Дмитро Клячківський «Клим Савур». - Рівне: видавець Олег Зень, 2009. - 168 с.

10. Марчук I. Командир УПА-Північ Дмитро Клячківський «Клим Савур» // Визвольний шлях. - 2004.- № 2 C. $88-105$.

11. Патриляк I.К. «Встань і борись! Слухай і вір...» українське націоналістичне підпілля та повстанський рух (1939-1960 рр.): монографія / I. Патриляк. - Львів: Центр досліджень визвольного руху. - Часопис, 2012. - 592 с.

12. Стародубець Г. Генеза українського повстанського запілля: монографія / Г. Стародубець. - Тернопіль: Підручники і посібники, 2008. - 464 с.

13. Стародубець Г. Діяльність організаційно-мобілізаційної референтури запілля УПА на зламі 1943 - 1944 рp. // Питання історії України: Зб. наук. ст. - Чернівці, 2004. T. 7 - С. 73-78.

14. Центральний державний архів вищих органів влади та управління України (далі - ЦДАВО України). Ф. 3838. - ОП. 1. - Спр. 59 - 207 арк.

15. ЦДАВО України. - On. 1. - Спр. 106 а. - 125 арк.

Надійшла до редколегії 19.12.2017 р.

Рецензент: В.C. Виздрик, доктор історичних наук, доцент, професор кафедри гуманітарних наук Національної академії сухопугних військ імені гетьмана Петра Сагайдачного, м. Львів

\section{Omelchenko Ihor}

\section{FORMATION AND ACTIVITY OF THE UNDERGROUND ORGANIZATIONAL MOBILIZATION DESKS (SECTIONS) OF THE UPA IN VOLYN AND POLISSIA (1943-1944)}

The article researches the features of the development of underground organizational mobilization desks of the UPA in Volyn and Polissia, their structure and composition based on the archival documents and materials. It also analyzes their main activity concepts, order of carrying out their tasks concerning the register of persons available to military service and conduct of mobilization to UPA, training activity and the organisation of the citizens' self-defence.

Key words: organizational mobilization desks, underground, Volyn, Polissia. 